\title{
The Influence of Osmotic Dehydration in Polyols Solutions on Sugar Profiles and Color Changes of Apple Tissue
}

\author{
Joanna Cichowska ${ }^{1 *}$, Łukasz Woźniak² ${ }^{2}$ Adam Figiel $^{3}$, Dorota Witrowa-Rajchert ${ }^{1}$ \\ 1 Department of Food Engineering and Process Management, Faculty of Food Sciences, Warsaw University of Life Sciences \\ (WULS-SGGW), 159c Nowoursynowska St., 02-776 Warsaw, Poland \\ 2 Department of Fruit and Vegetable Product Technology, Prof. Wacław Dąbrowski Institute of Agricultural and Food \\ Biotechnology, 36 Rakowiecka St., 02-532 Warsaw, Poland \\ 3 Institute of Agricultural Engineering, Wrocław University of Environmental and Life Sciences, 37a Chełmońskiego St., \\ 51-630 Wrocław, Poland \\ *Corresponding author, e-mail: joanna_cichowska@sggw.pl
}

Received: 28 March 2019, Accepted: 23 August 2019, Published online: 11 October 2019

\begin{abstract}
The following study aims to evaluate the changes in profile of selected sugars and content of polyols in the apple tissue after osmotic dehydration. What makes this research innovative is the use, in the osmotic pre-treatment, of solutions which have hitherto not been commonly used in fruit processing by researchers worldwide. Selected substances from the polyols group (erythritol, xylitol, and maltitol) were used as osmotic agents in $30 \%$ concentrated solutions. The ideal osmotic pressure, as well as efficiency of the process, was calculated, and these parameters were the highest in the case of erythritol. It was confirmed that type of osmotic solution and time of the process have significant influence on discussed parameters. Osmotic dehydration in polyols solutions resulted in increasing the content of these compounds during the process and minor changes in sugars profile of apple tissue. Color changes caused by pretreatment were small, but still they could be noticed by an inexperienced observer.
\end{abstract}

Keywords

sugar profiles, sugar alcohols, polyols, apple, osmotic dehydration

\section{Introduction}

Poland is one of the main major global producers of apples. The fruit is rich in nutrients, fiber, vitamins as well as it has antioxidant and antiproliferative activity $[1,2]$. According to Sun et al. [3], phenolic content in apple $(272.1 \pm 6.2 \mathrm{mg} /$ $100 \mathrm{~g})$ is higher compared to red grape $(182.0 \pm 2.6 \mathrm{mg} /$ $100 \mathrm{~g})$, strawberry $(147.8 \pm 1.1 \mathrm{mg} / 100 \mathrm{~g})$, lemon $(66.3 \pm 3.4 \mathrm{mg} / 100 \mathrm{~g})$, peach $(65.3 \pm 0.4 \mathrm{mg} / 100 \mathrm{~g})$, orange $(56.8 \pm 0.9 \mathrm{mg} / 100 \mathrm{~g})$, banana $(56.1 \pm 2.8 \mathrm{mg} / 100 \mathrm{~g})$, pear $(53.6 \pm 2.5 \mathrm{mg} / 100 \mathrm{~g})$, pineapple $(40.4 \pm 1.0 \mathrm{mg} / 100 \mathrm{~g})$, and grapefruit (30.7 $\pm 0.9 \mathrm{mg} / 100 \mathrm{~g})$. Apple also constitutes a source of sugar. According to USDA (The United States Department of Agriculture), one medium (182 g) apple contains almost $19 \mathrm{~g}$ of total sugars. However, the researchers $\mathrm{Hu}$ and Malik [4] showed that the detrimental effects of consuming high amounts of fructose had focused on soda and other packaged junk foods. Significantly lower risks of lung cancer were observed among the women who had increased consumption of apples and pears by 1 serving a day [5].
In the production of dried apples, osmotic dehydration (OD) as pre-treatment before drying is usually used to remove some part of the water from the tissue. Sucrose was the most common substance which was used for the preparation of osmotic solutions. Due to the pandemic of obesity as well as the rapidly growing incidence of type 2 diabetes in the community, it is extremely important to find new alternative solutions. The use of polyols as the osmotic agent in OD is an alternative to replace the sucrose because of its low calories and relative sweetness of around 60-100\% compared with sucrose. They are carbohydrates imparting a sweet sensation but are neither sugars nor alcohols [6]. Sugar alcohols (the polyols or polyhydric alcohols) are low digestible carbohydrates, which are obtained by substituting an aldehyde group with a hydroxyl one. Consumption of the products containing sugar alcohols do not induce an increase in blood glucose or insulin secretion, and thus, such products are recommended for the 
people with diabetes [7]. Because they are only partially (if at all) digested and absorbed in the small intestine, low-digestible carbohydrates can have a laxative effect when consumed in excessive amounts [8].

Firmness and sugar content are important quality attributes that directly influence consumers on purchasing fresh apple fruit [9]. The concentrations of individual carbohydrates (e.g. fructose, glucose, sucrose, sorbitol) show characteristic changes during fruit development after bloom [10]. In terms of sugar composition, fructose and glucose are the predominant sugars for most apple varieties [11]. The sugar content of apples differs depending on the weather conditions, cultivars, culture technology, position and exposition of the fruits in the crown [12]. During storage, the content of sucrose, fructose, and glucose decrease significantly in some varieties, while increased in others [13]. It is known that the presence of sugar in food lowers the water activity of the food. Ultrasonic pretreatment enhances the removal of soluble solids (sugars) from the fruit to the liquid medium [14].

In previous research, many results of sugars composition in apples were reported [15-17], but the scientists rarely mentioned how it changed after osmotic dehydration in sugar alcohol solutions. The potential for use sorbitol was confirmed by Assis et al. [18]. Moreover, Bialik et al. [19] and Cichowska et al. [20] used xylitol and maltitol as an alternative to sucrose solutions during OD. Authors also reported possibility of the use dihydroxyacetone (DHA) as osmotic agent in this process [21].

The aim of this study was to evaluate changes in profile of selected sugars and content of polyols in the apple tissue after osmotic dehydration as well as color changes caused by pre-treatment.

\section{Materials and methods}

Fresh apples of the Paulared variety were purchased from a local shop. The fruits were stored at $4-5{ }^{\circ} \mathrm{C}$ and relative humidity of $85-90 \%$ in a refrigerator until use. Before the experiment, the apples were washed, stoned and cut into triangular slices (with a peel), each slice was $5 \mathrm{~mm}$ thick.

\subsection{Pre-treatment procedure}

The slices (40 $\pm 2 \mathrm{~g}$ ) were dehydrated by osmotic dehydration (OD) in a water bath (Water Bath Shaker Type 357 ELPAN, Poland) with continuous shaking (1 Hz amplitude). The temperature of water bath was constant. Apple samples were dipped into $30 \%$ concentrated syrups. Osmotic solutions were prepared with selected substances from the polyol group: erythritol, xylitol, and maltitol (Brenntag, Kędzierzyn-Koźle, Poland) with distilled water. Osmotic dehydration was carried out in the range from 0.5 to 6 hours at the temperature of $40^{\circ} \mathrm{C}$ (atmospheric pressure) and with 2:1 the syrup-to-fruit ratio. Afterwards, samples were removed from the osmotic solution and blotted with absorbent paper to remove osmotic liquid from their surface. Samples were weighed and dry matter, as well as water loss and solid gain, were determined (according to Cichowska et al. [20]). Two technological repetitions were performed for each treatment.

\subsection{Efficiency of OD}

The efficiency of OD (Eq. (3)) was calculated as ratio water loss (WL - Eq. (1)) to solid gain (SG - Eq. (2)) during process. These parameters were calculated and discussed in previous research of Authors [20]:

$$
\begin{aligned}
& \mathrm{WL}=\frac{\left(1-s_{o}\right) \times m_{o}-\left(1-s_{\tau}\right) \times m_{\tau}}{s_{o} \times m_{o}}, \\
& \mathrm{SG}=\frac{s_{\tau} \times m_{\tau}-s_{o} \times m_{o}}{s_{o} \times m_{o}}, \\
& \text { Efficiency }=\frac{\mathrm{WL}}{\mathrm{SG}} .
\end{aligned}
$$

\subsection{Dry matter content [22]}

Dry matter content was measured in two repetitions for each sample. The weighted material $(\sim 2 \mathrm{~g})$ placed in a weighing glass was dried in a convective dryer (SUP-65 WG WAMED, Poland) at the temperature of $70{ }^{\circ} \mathrm{C}$ until the weight was constant. Then, the material was cooled and weighed on an analytical scale with the accuracy of $0.001 \mathrm{~g}$.

\subsection{Packaging and storage}

After osmotic dehydration, the samples were packed into plastic polyethylene bags (BOPA/PE 15/40 FF) and then packs were welded using an impulse sealer (Hualian Machinery, China). The weight of the apple inside the pack of single stored package was approximately $12 \mathrm{~g}$. Then they were stored in a freezer (F6181AW, GORENJE, Slovenia) at $-18{ }^{\circ} \mathrm{C}$ before analyzes.

\subsection{Determination of sugar profile and polyols content}

The chromatographic analyses were performed using Waters (Milford, MA, USA) equipment: 2695 Separations Module and 2414 Refractive Index Detector. Glucose, fructose, sucrose, and polyols were quantified according to 
the modified version of EN 12630:1999 standard. During the analysis, a Sugar-Pak I, $10 \mu \mathrm{m}, 6.5 \mathrm{~mm} \times 300 \mathrm{~mm}$ column with a Sugar-Pak Guard-Pak insert, $10 \mu \mathrm{m}$ (both Waters), were kept at a temperature of $90{ }^{\circ} \mathrm{C}$. The samples $(10 \mu \mathrm{L})$ were eluted isocratically, using $0.1 \mathrm{mM}$ calcium disodium EDTA within $20 \mathrm{~min}$ at a flow rate of $0.5 \mathrm{~mL} / \mathrm{min}$. The compounds were quantified, using a refractive index detector.

\subsection{Color measurement}

Color analysis of the osmo-dehydrated apples surface was determined with the use of Minolta Chroma Meter CR-200 (Minolta Corp., Osaka, Japan). The measurement conditions were: D65 standard illuminate, $2^{\circ}$ Standard Observer, measurement diameter: $30 \mathrm{~mm}$. The results were presented using the directly measured parameters: $L^{*}$ (lightness/darkness), $a^{*}$ (red/green), $b^{*}$ (yellow/blue). The measurements were made in 5 repetitions for every sample; the mean values are reported. The total color difference $(\Delta E)$ and Chroma $(C$, relative saturation) were calculated according to the following formulas (Eqs. (4), (5)):

$$
\begin{aligned}
& \Delta E=\sqrt{\left(\Delta L^{*}\right)^{2}+\left(\Delta a^{*}\right)^{2}+\left(\Delta b^{*}\right)^{2}} \\
& C^{*}=\sqrt{a^{* 2}+b^{* 2}}
\end{aligned}
$$

$\Delta L^{*}, \Delta a^{*}, \Delta b^{*}$ - the change of $L^{*}, a^{*}$, and $b^{*}$ parameter between raw material and samples after pre-treatment.

\subsection{Statistical analysis}

The statistical software Statgraphics Plus ver. 5.1 (StatPoint) and Excel 2016 (Microsoft) were used for data analysis. The influence of pre-treatment (duration of the process, type of osmotic solution) on dependent variables: (dry matter content, the efficiency of OD as well as sugars content and color changes) was evaluated by means of a multifactorial analysis of variance (ANOVA) at a significance level $\alpha=0.05$. In the case of significant associations, post-hoc Tukey's test was performed.

\section{Results and discussion}

\subsection{Dry matter content}

The raw material was characterized by $12 \pm 0.10 \%$ of dry matter content (Table 1). The similar result was observed by Ticha et al. [16] in Ontario cultivar, by Devic et al. [23] in Gala, Guillevic and Marie Menard cultivars. Research Campeanu et al. [9] was conducted on 10 apple cultivars the achieved values of dry matter content were between $11.63-21.31 \%$. The most similar dry matter content to this research was in the case of $\mathrm{H}-4 / 50$ cultivar from a
Table 1 Dry matter content in apples during OD in different solutions $(\%)$

\begin{tabular}{lccc}
\hline $\begin{array}{l}\text { Solution } \\
\text { Time }\end{array}$ & Erythritol & Xylitol & Maltitol \\
\hline 0 & $12.03 \pm 0.8$ & $12.03 \pm 0.8$ & $12.03 \pm 0.8$ \\
30 & $20.33 \pm 0.0$ & $18.92 \pm 1.0$ & $15.53 \pm 0.2$ \\
60 & $24.19 \pm 0.4$ & $20.38 \pm 2.0$ & $17.45 \pm 0.7$ \\
120 & $25.82 \pm 1.5$ & $24.30 \pm 0.5$ & $21.36 \pm 1.0$ \\
180 & $30.95 \pm 0.5$ & $24.68 \pm 0.7$ & $19.72 \pm 0.7$ \\
240 & $29.89 \pm 0.5$ & $27.40 \pm 0.2$ & $20.57 \pm 0.3$ \\
360 & $29.35 \pm 0.2$ & $26.85 \pm 0.4$ & $21.95 \pm 0.3$ \\
\hline
\end{tabular}

microculture from 2001 year at the Voinesti Tree Society. The value of this parameter relates to fruit cultivar/variety. A lot of researchers have been reported higher values of dry matter content, compared to this raw material, e.g. between 13.6 - $19.3 \%$ (19 cultivars of apples) [2], $14.6-17.9 \%$ (3 cultivars) [24], $14-15 \%$ (2 varieties) [25].

During osmotic dehydration of apples in polyols solutions, increase values of dry matter content were observed (Table 1). In this experiment, erythritol was determined as the most effective osmotic agent for reaching high dry matter values. It is worth mentioning that the highest value was observed after $180 \mathrm{~min}$ of the process. This suggests that it is not necessary to dehydrate the apple slices in solutions for periods longer than 3 hours. Statistical analysis also confirmed this statement - the values achieved after 3 and more hours were classified to one homogeneous group (Table 2).

An increase of dry matter in apple tissue was the result of penetration soluble solids from osmotic solution. Erythritol

Table 2 The influence of osmotic pre-treatment in a different type of solutions (Ery - erythritol, Xyl - xylitol, Mal - maltitol) and time on dry matter content in fruits

\begin{tabular}{llcccc}
\hline Factor & & $P$-value & Contrast & + - Limits & Difference \\
\hline $\begin{array}{l}\text { Type of } \\
\text { osmotic } \\
\text { solution }\end{array}$ & Ery $^{\mathrm{c}}$ & & Ery-Mal & 0.0146 & $0.0419^{*}$ \\
& $\mathrm{Xyl}^{\mathrm{b}}$ & $0.000^{*}$ & Ery-Xyl & 0.0146 & $0.0172^{*}$ \\
& $0^{\mathrm{a}}$ & & Mal-Xyl & 0.0146 & $0.0045^{*}$ \\
\hline \multirow{2}{*}{$\begin{array}{l}\text { Time } \\
\text { (min) }\end{array}$} & $30^{\mathrm{b}}$ & & $0-30$ & 0.0271 & $-0.0621^{*}$ \\
& $120^{\mathrm{bc}}$ & & $30-60$ & 0.0347 & -0.0241 \\
& $180^{\mathrm{d}}$ & $0.000^{*}$ & $120-180$ & 0.0347 & -0.0765 \\
& $240^{\mathrm{d}}$ & & $180-240$ & 0.0347 & -0.0084 \\
& $360^{\mathrm{d}}$ & & $240-360$ & 0.0347 & -0.0009 \\
\end{tabular}

Statistical differences between factors; a Tukey test of main effects was performed. * denotes a statistically significant difference. Means within columns with a different lowercase letter superscript are significantly different $(p<0.05)$. 
solution turned out to be the most effective - the values were higher than the ones achieved in other solutions (Table 1).

\subsection{Efficiency of OD}

The Authors of this paper reported in the previous research the modeling of water loss and solid gain during osmotic dehydration, using Peleg's model [20]. Their results showed the efficiency of OD in polyols solutions (xylitol, erythritol, and maltitol) and lack of effectiveness in the case of oligofructose and inulin solutions. An initial rapid rate of mass transfer was observed for the first three hours of the process, so OD for periods longer than $3 \mathrm{~h}$ was not effective. The highest values of water loss (in the case of $30 \%$ concentration) were obtained after $180 \mathrm{~min}$, when erythritol was used ( $3.17 \mathrm{~g} / \mathrm{g}$ i.d.m), while in the case of xylitol and maltitol the values were much lower (2.22 and $1.17 \mathrm{~g} / \mathrm{g}$ i.d.m, respectively). The same relationship was observed in parameter of solid gain. The values obtained for the samples treated by erythritol, xylitol, and maltitol after $180 \mathrm{~min}$ of the process were equal to $0.86,0.67$ and $0.51 \mathrm{~g} / \mathrm{g}$ i.d.m., respectively. In this experiment, the efficiency of OD was calculated as ratio water loss to solid gain during process in different osmotic agents separately. The higher the ratio of water loss/solute uptake, the greater the efficiency of the osmotic dehydration process is considered to be. The results are shown in Fig. 1.

At the beginning of the OD process, the advantage of WL over SG for xylitol was almost four times, and in the case of maltitol - only 2.5 times. The greatest efficiency was achieved when erythritol or xylitol was used (white and light grey bars) - the values were classified into one homogenous group (Table 3). It was due to the difference in osmotic pressure between the osmotic solution and the food. This was caused by the molecular weight of the solutes used. Higher osmotic pressure had erythritol $(122.12 \mathrm{~g} / \mathrm{mol})$ and xylitol $(152.15 \mathrm{~g} / \mathrm{mol})$ because of lower

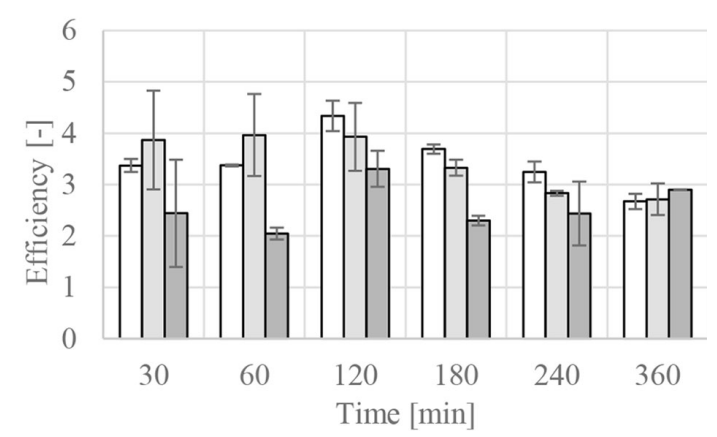

Fig. 1 Efficiency of OD in $30 \%$ concentrated polyols solutions: erythritol (white bars), xylitol (light grey bars), maltitol (dark grey bars)
Table 3 The influence of osmotic pre-treatment in a different type of solutions (Ery - erythritol, Xyl - xylitol, Mal - maltitol) and time on efficiency of OD

\begin{tabular}{llcccc}
\hline Factor & & $P$-value & Contrast & + - Limits & Difference \\
\hline $\begin{array}{l}\text { Type of } \\
\text { osmotic } \\
\text { solution }\end{array}$ & Ery $^{\mathrm{b}}$ & & Ery-Mal & 0.5280 & $0.8774^{\mathrm{b}}$ \\
& $\mathrm{Mal}^{\mathrm{a}}$ & $0.000^{*}$ & Ery-Xyl & 0.5280 & 0.0102 \\
& $30^{\mathrm{ab}}$ & & Mal-Xyl & 0.5280 & $-0.8672^{*}$ \\
\hline & $60^{\mathrm{ab}}$ & & $30-60$ & 0.9222 & 0.0981 \\
Time & $120^{\mathrm{b}}$ & $0.018^{*}$ & $120-180$ & 0.9222 & 0.7513 \\
$(\mathrm{~min})$ & $180^{\mathrm{ab}}$ & & $180-240$ & 0.9222 & 0.2676 \\
& $240^{\mathrm{a}}$ & & $240-360$ & 0.9222 & 0.0768 \\
& $360^{\mathrm{a}}$ & & $360-30$ & 0.9222 & 0.3665 \\
\hline
\end{tabular}

Statistical differences between factors; a Tukey test of main effects was performed. * denotes a statistically significant difference. Means within columns with a different lowercase letter superscript are significantly different $(p<0.05)$.

molecular weight compared to maltitol $(344.31 \mathrm{~g} / \mathrm{mol})$. During osmotic dehydration, the phenomenon of water loss mainly occurred. This fact was confirmed also by Bialik et al. [19], who dehydrated kiwiberry. Process time had a significant influence on this parameter. The highest values of efficiency were noticed after 2 hours of the process (Fig. 1). With extending of OD duration, the decrease of values was observed. It was caused by following decrease in water loss together with solid gain. The lower the water content of the sample, the more difficult it is for sugar to diffuse into the fruit tissues [26].

\subsection{Sugar profiles}

The interpretation of the sugar profile was interfered with changes in water and solid content during osmotic dehydration. It was related to water loss and simultaneously loss soluble compounds from apple extract (include sugars) and, on the other hand, penetration of the solution components into the fruit tissue. Changes in profile of selected sugars and content of polyols in the apple tissue during process are shown in Fig. 2.

In apples raw tissue, the amount of fructose was the most abundant among sugars, followed by sucrose, glucose and trace amounts of sorbitol. The results were similar to the ones achieved by Chareoansiri and Kongkachuichai [25] and Begić-Akagić et al. [15]. The second group of scientists also reported that cultivar had a significant influence on individual sugars and organic acid in the fruit. Amount of fructose in raw apple material Paulared variety was approx. $70 \mathrm{~g} / \mathrm{kg}$ fresh weight (Fig. 2). The value was higher compared to selected 

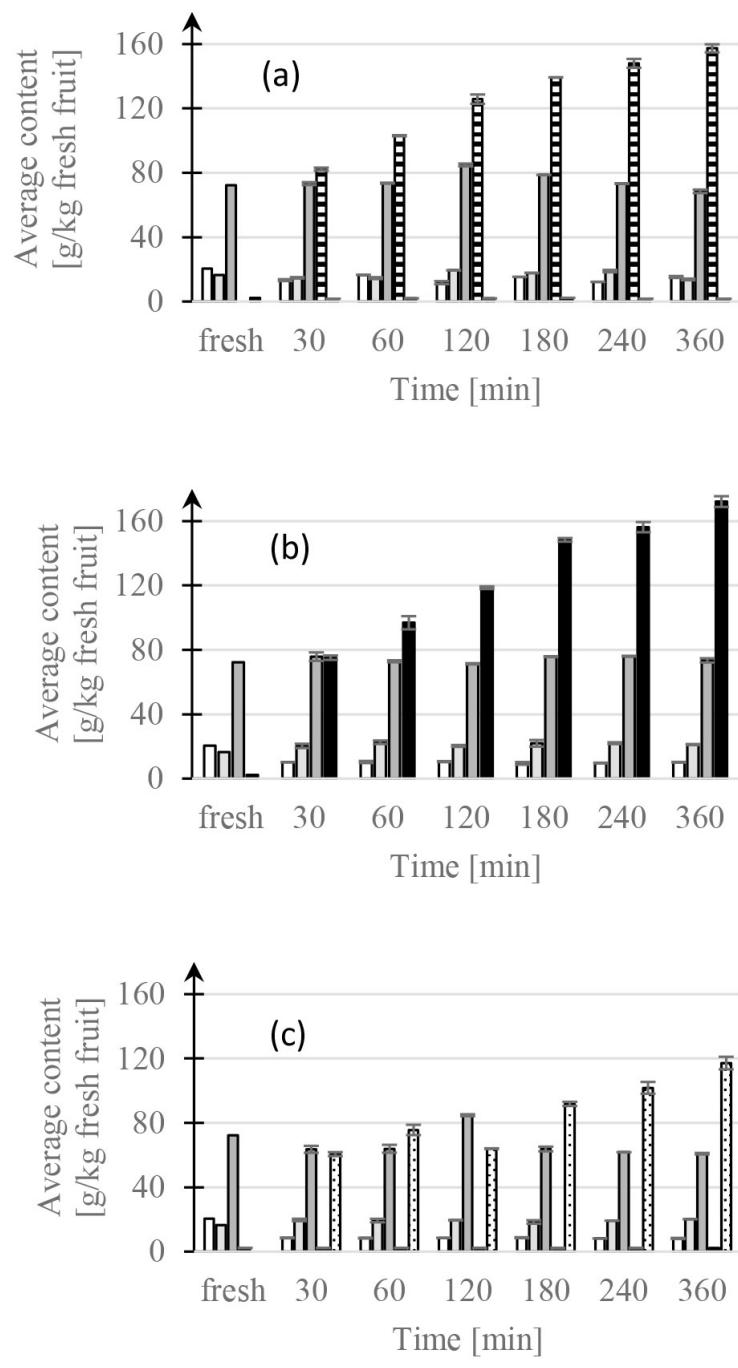

Fig. 2 Sugar profile and polyols content after $\mathrm{OD}$ at $40^{\circ} \mathrm{C}$, using different solutions: (a) erythritol, (b) xylitol, (c) maltitol. Legend: sucrose (white bars), glucose (light grey bars), fructose (dark grey bars), sorbitol + xylitol (black bars), erythritol (striped bars), maltitol (dotted bars)

12 cultivars in the research by Begić-Akagić et al. [15]. However, in the case of glucose, the situation was opposite, with achieved values not exceeding $20 \mathrm{~g} / \mathrm{kg}$ fresh weight. Three cultivars: Prijedorska zelenika, Paradija, Funtaca showed similar level of sucrose in the apple tissue [15]. Nevertheless, the content of sorbitol was far smaller in comparison to values obtained in this research (Fig. 2). Comparable results of marked sugars have been reported by Zupan et al. [17] in the case of Delicious cultivar without watercore. According to them, watercore has an influence on apple fruit sugar and phenol content, even before any visual signs of internal breakdown and browning. The same composition of sugars in the apple tissue as Paulared variety was also observed by Devic et al. [23] in Gala cultivar, by Ticha et al. [16] in Melrose cultivar and by Li et al. [27] in Red delicious, in contrast to research carried out by Füzfai et al. [28]. Four selected varieties of apples (Idared, Liberty, Pilot, Pinova) showed different sugar profile. The values of major sugar - fructose did not exceed $55 \%$, level of glucose was lower, but in the case of sorbitol - higher. Also, Wang et al. [29] have reported different results of sugar profiles in 62 heritage apple cultivars - marked values of glucose were higher, but fructose content was in large part lower. A similar sugar profile was observed only in one industry cultivar Hibernal.

Sorbitol, the major sugar alcohol in apples, was present in concentrations approx. $2.3 \mathrm{~g} / \mathrm{kg}$ fresh weight (Fig. 2). The chromatographic analyses allowed to mark sorbitol content together with xylitol content. Because of this fact and due to low content, this kind of sugar was omitted in the statistical analysis. The values of sorbitol content observed by researchers, related to a cultivar of fruit. Aprea et al. [30] noted values between 1.3 and $12.9 \mathrm{~g} / \mathrm{kg}$ (average $5.5 \mathrm{~g} / \mathrm{kg}$ ) in 17 different cultivar/accessions. Wider range of the level of sorbitol has been reported by Wang et al. [29] - between 0.0 and $15.3 \mathrm{~g} / \mathrm{L}$ (average $4.3 \mathrm{~g} / \mathrm{L}$ ) - the values marked in 62 apple cultivars. Sorbitol is preferentially converted into fructose while glucose is preferentially incorporated into starch [31]. In apples, only a small fraction of fructose is incorporated into starch; fructose, instead of that, accumulates in the vacuoles of apple cells. As a result, the level of fructose is always higher than the one of glucose in fruit tissue [30].

Osmotic dehydration in polyols solutions resulted in increasing the content of these compounds during process (Fig. 2). At the end of OD, the content of erythritol, xylitol, and maltitol in apple tissue was approximately two times higher compared to the values achieved after 30 minutes. The most values were obtained in the case of use erythritol as osmotic agent until 2 hours, whereas in the range of 3 to 6 hours in the case of xylitol (Fig. 2 (a), (b)). Significantly lower content of polyols was marked in apple tissue, which was dehydrated in maltitol solution (Fig. 2 (c)). This phenomenon can be explained by differences in osmotic pressure between solution and fruit, which is the driving force of the process. The ideal osmotic pressure was calculated according to Held et al. [32] for each solution separately. The highest ideal osmotic pressure was observed in the case of erythritol $(6396.87 \mathrm{kPa})$, a bit lower in the case of xylitol (5134.16 kPa) and small in the case of maltitol solution $(2270.28 \mathrm{kPa})$. The first two solutions were characterized by osmotic pressure higher than $60 \%$ concentrated solutions of sucrose 
and maltitol obtained by Bialik et al. [19]. The value of this parameter in the case of use $60 \%$ concentrated solution of xylitol was approximately two times higher. After osmotic dehydration in xylitol and maltitol solutions the sucrose content was approximately two times lower and glucose content was slightly higher (Fig. 2 (b), (c)), but the influence of time was insignificant (Tables 4, 5).

Statistical analysis showed significant influence of OD time ( $p$-Value: $0.002, \alpha=0.05$ ) and type of osmotic agent ( $p$-Value: $0.000, \alpha=0.05$ ) on achieved values of fructose content (Table 6). Values achieved when erythritol and xylitol were used, were classified into one homogenous group.

After osmotic dehydration in sucrose solution, Devic et al. [23] observed sucrose gain as well as fructose loss.

Table 4 The influence of osmotic pre-treatment in a different type of solutions (Ery - erythritol, Xyl - xylitol, Mal - maltitol) and time on sucrose content $(\mathrm{g} / \mathrm{kg}$ fresh weight) in apple tissue

\begin{tabular}{llcccc}
\hline Factor & & $P$-value & Contrast & + - Limits & Difference \\
\hline $\begin{array}{l}\text { Type of } \\
\text { osmotic }\end{array}$ & Ery $^{\mathrm{c}}$ & & Ery-Mal & 1.0456 & $5.6588^{*}$ \\
Solution & $\mathrm{Xyl}^{\mathrm{b}}$ & $0.000^{*}$ & Ery-Xyl & 1.0456 & $4.0155^{*}$ \\
& Mal $^{\mathrm{a}}$ & & Mal-Xyl & 1.0456 & $-1.6434^{*}$ \\
\hline & $30^{\mathrm{a}}$ & & $30-60$ & 1.8261 & -1.0856 \\
& $60^{\mathrm{a}}$ & & $60-120$ & 1.8261 & 1.4886 \\
Time & $120^{\mathrm{a}}$ & 0.065 & $120-180$ & 1.8261 & -0.8758 \\
$(\mathrm{~min})$ & $180^{\mathrm{a}}$ & & $180-240$ & 1.8261 & 1.1377 \\
& $240^{\mathrm{a}}$ & & $240-360$ & 1.8261 & -1.1983 \\
& $360^{\mathrm{a}}$ & & $360-30$ & 1.8261 & -0.5334 \\
\hline
\end{tabular}

Statistical differences between factors; a Tukey test of main effects was performed. * denotes a statistically significant difference. Means within columns with a different lowercase letter superscript are significantly different $(p<0.05)$.

Table 5 The influence of osmotic pre-treatment in a different type of solutions (Ery - erythritol, Xyl - xylitol, Mal - maltitol) and time on glucose content $(\mathrm{g} / \mathrm{kg}$ fresh weight) in apple tissue

\begin{tabular}{|c|c|c|c|c|c|}
\hline Factor & & $P$-value & Contrast & $+/-$ Limits & Difference \\
\hline \multirow{3}{*}{$\begin{array}{l}\text { Type of } \\
\text { osmotic } \\
\text { solution }\end{array}$} & Ery $^{a}$ & \multirow{3}{*}{$0.000 *$} & Ery-Mal & 1.5864 & $-2.8546^{*}$ \\
\hline & $\mathrm{Xyl}{ }^{\mathrm{c}}$ & & Ery-Xyl & 1.5864 & $-4.8512 *$ \\
\hline & $\mathrm{Mal}^{\mathrm{b}}$ & & Mal-Xyl & 1.5864 & $-1.9966^{*}$ \\
\hline \multirow{6}{*}{$\begin{array}{l}\text { Time } \\
(\mathrm{min})\end{array}$} & $30^{\mathrm{a}}$ & \multirow{6}{*}{0.264} & $30-60$ & 2.7706 & -0.5736 \\
\hline & $60^{\text {a }}$ & & $60-120$ & 2.7706 & -0.9473 \\
\hline & $120^{\mathrm{a}}$ & & $120-180$ & 2.7706 & 0.3859 \\
\hline & $180^{a}$ & & $180-240$ & 2.7706 & -0.6831 \\
\hline & $240^{a}$ & & $240-360$ & 2.7706 & 1.7118 \\
\hline & $360^{a}$ & & $360-30$ & 2.7706 & -0.1062 \\
\hline
\end{tabular}

Statistical differences between factors; a Tukey test of main effects was performed. * denotes a statistically significant difference. Means within columns with a different lowercase letter superscript are significantly different $(p<0.05)$.
Table 6 The influence of osmotic pre-treatment in a different type of solutions (Ery - erythritol, Xyl - xylitol, Mal - maltitol) and time on fructose content ( $\mathrm{g} / \mathrm{kg}$ fresh weight) in apple tissue

\begin{tabular}{cccccc}
\hline \multicolumn{2}{c}{ Factor } & $P$-value & Contrast & + - Limits & Difference \\
\hline \multirow{2}{*}{$\begin{array}{c}\text { Type of } \\
\text { osmotic }\end{array}$} & Ery $^{\mathrm{b}}$ & & Ery-Mal & 4.7684 & $8.9343^{*}$ \\
solution & $\mathrm{Xyl}^{\mathrm{b}}$ & $0.000^{*}$ & Ery-Xyl & 4.7684 & 1.1560 \\
& $\mathrm{Mal}^{\mathrm{a}}$ & & Mal-Xyl & 4.7684 & $-7.7783^{*}$ \\
\hline \multirow{6}{*}{$30^{\mathrm{a}}$} & & $30-60$ & 8.3277 & 0.7278 \\
& $60^{\mathrm{a}}$ & & $60-120$ & 8.3277 & $-10.1807^{*}$ \\
Time & $120^{\mathrm{b}}$ & & $120-180$ & 8.3277 & 7.5899 \\
& $180^{\mathrm{ab}}$ & $0.002^{*}$ & $180-240$ & 8.3277 & 2.3434 \\
& $240^{\mathrm{a}}$ & & $240-360$ & 8.3277 & 2.7917 \\
& $360^{\mathrm{a}}$ & & $360-30$ & 8.3277 & 3.2722 \\
\hline
\end{tabular}

Statistical differences between factors; a Tukey test of main effects was performed. * denotes a statistically significant difference. Means within columns with a different lowercase letter superscript are significantly different $(p<0.05)$.

During the same process in the polyols solutions, fructose loss was noticed in the case of erythritol and maltitol (Fig. 2 (a), (c)). Using xylitol, the level of fructose was almost the same as from the beginning (Fig. 2 (b)).

Aprea et al. [30] quantified the major sugars (sucrose, glucose, fructose, xylose) and sorbitol and explored their influence on perceived sweetness in an apple. According to them, there is no direct interaction between the ratios of different sugars and sweetness.

\subsection{Color changes}

Color is an important quality in dried foods. According to Mothibe et al. [14], this is the first parameter which customers use in order to judge the quality of dried products. If the color of dried fruits is dark, then its quality is poor. Pretreatment before drying can also have an influence on color changes. Therefore, it is important to observe these changes during osmotic dehydration. During this process, the loss of color is one of the most significant changes [33]. Under the influence of the technological processes application, appearance changes in samples occurred (Table 7).

During osmotic dehydration of apples in erythritol solution, an increase of brightness and parameter $a^{*}$ were observed. The brightness could be higher due to sugar coating, which appeared as a result after a process of OD. This substance has a high crystallization capacity [34]. The opposite situation in the case of brightness was noticed when other polyols as osmotic agents had been used. The achieved values were classified into one homogenous group. According to Ciurzyńska et al. [35], an osmotic solution type and temperature have significant 
Table 7 The influence of osmotic pre-treatment in a different type of solutions and time on color parameters in fruit

\begin{tabular}{|c|c|c|c|c|c|c|c|c|c|c|c|c|c|c|c|}
\hline \multirow{2}{*}{$\begin{array}{l}\text { Osmotic agent } \\
\text { Parameter } \\
\text { Time (min) }\end{array}$} & \multicolumn{5}{|c|}{ Erythritol } & \multicolumn{5}{|c|}{ Xylitol } & \multicolumn{5}{|c|}{ Maltitol } \\
\hline & $L^{*}$ & $a^{*}$ & $b^{*}$ & $C$ & $\Delta E$ & $L^{*}$ & $a^{*}$ & $b^{*}$ & $C$ & $\Delta E$ & $L^{*}$ & $a^{*}$ & $b^{*}$ & $C$ & $\Delta E$ \\
\hline 0 & $\begin{array}{c}78.8 \\
\pm 1.2^{\text {a }}\end{array}$ & $\begin{array}{l}-2.1 \\
\pm 0.1^{\mathrm{a}}\end{array}$ & $\begin{array}{c}12.7 \\
\pm 0.9^{\mathrm{a}}\end{array}$ & $\begin{array}{c}12.9 \\
\pm 2.0^{\mathrm{a}}\end{array}$ & - & $\begin{array}{c}78.8 \\
\pm 1.2^{\text {a }}\end{array}$ & $\begin{array}{l}-2.1 \\
\pm 0.1^{\text {a }}\end{array}$ & $\begin{array}{c}12.7 \\
\pm 0.9^{\mathrm{a}}\end{array}$ & $\begin{array}{c}12.9 \\
\pm 2.0^{\mathrm{a}}\end{array}$ & - & $\begin{array}{c}78.8 \\
\pm 1.2^{\mathrm{bc}}\end{array}$ & $\begin{array}{l}-2.1 \\
\pm 0.1^{\mathrm{a}}\end{array}$ & $\begin{array}{c}12.7 \\
\pm 0.9^{\mathrm{a}}\end{array}$ & $\begin{array}{c}12.9 \\
\pm 2.0^{\mathrm{a}}\end{array}$ & - \\
\hline 30 & $\begin{array}{c}80.4 \\
\pm 0.4^{\mathrm{a}}\end{array}$ & $\begin{array}{c}-2.7 \\
\pm 0.5^{\text {a }}\end{array}$ & $\begin{array}{c}12.0 \\
\pm 2.0^{\mathrm{a}}\end{array}$ & $\begin{array}{c}13.0 \\
\pm 1.6^{\mathrm{a}}\end{array}$ & 1.9 & $\begin{array}{c}78.3 \\
\pm 2.1^{\mathrm{a}}\end{array}$ & $\begin{array}{l}-1.2 \\
\pm 1.0^{\mathrm{a}}\end{array}$ & $\begin{array}{c}16.6 \\
\pm 2.6^{\mathrm{a}}\end{array}$ & $\begin{array}{c}16.2 \\
\pm 2.4^{\mathrm{a}}\end{array}$ & 5.4 & $\begin{array}{c}79.3^{1} \\
\pm 0.1^{\mathrm{c}}\end{array}$ & $\begin{array}{l}-2.3 \\
\pm 0.1^{\mathrm{a}}\end{array}$ & $\begin{array}{c}12.4 \\
\pm 0.5^{\text {a }}\end{array}$ & $\begin{array}{c}12.6 \\
\pm 0.6^{\mathrm{a}}\end{array}$ & 0.6 \\
\hline 60 & $\begin{array}{c}80.6 \\
\pm 0.2^{\mathrm{a}}\end{array}$ & $\begin{array}{l}-2.5 \\
\pm 0.1^{\mathrm{a}}\end{array}$ & $\begin{array}{c}12.9 \\
\pm 1.3^{\mathrm{a}}\end{array}$ & $\begin{array}{c}13.0 \\
\pm 1.7^{\mathrm{a}}\end{array}$ & 1.8 & $\begin{array}{c}72.6 \\
\pm 1.0^{\mathrm{a}}\end{array}$ & $\begin{array}{l}-0.8 \\
\pm 0.6^{\mathrm{a}}\end{array}$ & $\begin{array}{c}18.8 \\
\pm 2.8^{\mathrm{a}}\end{array}$ & $\begin{array}{c}18.8 \\
\pm 2.6^{\mathrm{a}}\end{array}$ & 8.9 & $\begin{array}{c}79.4 \\
\pm 1.0^{\mathrm{c}}\end{array}$ & $\begin{array}{l}-2.2 \\
\pm 0.4^{\mathrm{a}}\end{array}$ & $\begin{array}{c}14.0 \\
\pm 0.7^{\mathrm{a}}\end{array}$ & $\begin{array}{c}14.2 \\
\pm 1.0^{\mathrm{ab}}\end{array}$ & 1.4 \\
\hline 120 & $\begin{array}{c}80.5 \\
\pm 1.5^{\text {a }}\end{array}$ & $\begin{array}{l}-2.6 \\
\pm 0.3^{\mathrm{a}}\end{array}$ & $\begin{array}{c}14.4 \\
\pm 1.5^{\mathrm{a}}\end{array}$ & $\begin{array}{c}14.6 \\
\pm 1.4^{\mathrm{a}}\end{array}$ & 2.4 & $\begin{array}{c}74.1 \\
\pm 1.5^{\text {a }}\end{array}$ & $\begin{array}{l}-2.0 \\
\pm 0.2^{\mathrm{a}}\end{array}$ & $\begin{array}{c}14.7 \\
\pm 1.6^{\mathrm{a}}\end{array}$ & $\begin{array}{c}14.8 \\
\pm 0.8^{\mathrm{a}}\end{array}$ & 5.2 & $\begin{array}{c}78.7 \\
\pm 0.2^{\mathrm{bc}}\end{array}$ & $\begin{array}{c}-3.4 \\
\pm 0.5^{\mathrm{a}}\end{array}$ & $\begin{array}{c}15.0 \\
\pm 1.8^{\mathrm{a}}\end{array}$ & $\begin{array}{c}15.4 \\
\pm 1.7^{\text {ab }}\end{array}$ & 2.6 \\
\hline 180 & $\begin{array}{c}80.8 \\
\pm 1.6^{\mathrm{a}}\end{array}$ & $\begin{array}{c}-2.9 \\
\pm 0.2^{\mathrm{a}}\end{array}$ & $\begin{array}{c}14.8 \\
\pm 1.0^{\mathrm{a}}\end{array}$ & $\begin{array}{c}13.8 \\
\pm 1.1^{\mathrm{a}}\end{array}$ & 2.9 & $\begin{array}{c}71.7 \\
\pm 1.2^{\text {a }}\end{array}$ & $\begin{array}{c}-1.2 \\
\pm 0.2^{\mathrm{a}}\end{array}$ & $\begin{array}{c}11.7 \\
\pm 0.8^{\text {a }}\end{array}$ & $\begin{array}{c}11.8 \\
\pm 0.3^{\mathrm{a}}\end{array}$ & 7.2 & $\begin{array}{c}72.9 \\
\pm 0.9^{\mathrm{a}}\end{array}$ & $\begin{array}{c}-1.5 \\
\pm 0.7^{\mathrm{a}}\end{array}$ & $\begin{array}{c}19.9 \\
\pm 2.3^{\mathrm{a}}\end{array}$ & $\begin{array}{c}20.4 \\
\pm 1.1^{\mathrm{b}}\end{array}$ & 9.4 \\
\hline 240 & $\begin{array}{c}79.2 \\
\pm 1.1^{\mathrm{a}}\end{array}$ & $\begin{array}{c}-2.7 \\
\pm 0.3^{\mathrm{a}}\end{array}$ & $\begin{array}{c}17.0 \\
\pm 2.1^{\mathrm{a}}\end{array}$ & $\begin{array}{c}16.3 \\
\pm 1.5^{\text {a }}\end{array}$ & 4.3 & $\begin{array}{c}71.8 \\
\pm 3.2^{\mathrm{a}}\end{array}$ & $\begin{array}{l}-0.8 \\
\pm 1.3^{\mathrm{a}}\end{array}$ & $\begin{array}{c}15.4 \\
\pm 3.0^{\mathrm{a}}\end{array}$ & $\begin{array}{c}15.4 \\
\pm 2.8^{\mathrm{a}}\end{array}$ & 7.7 & $\begin{array}{c}73.7 \\
\pm 1.2^{\mathrm{a}}\end{array}$ & $\begin{array}{l}-2.2 \\
\pm 0.3^{\mathrm{a}}\end{array}$ & $\begin{array}{c}16.3 \\
\pm 0.7^{\mathrm{a}}\end{array}$ & $\begin{array}{c}16.6 \\
\pm 0.5^{\mathrm{ab}}\end{array}$ & 6.3 \\
\hline 360 & $\begin{array}{c}79.6 \\
\pm 0.9^{\text {a }}\end{array}$ & $\begin{array}{l}-2.5 \\
\pm 0.1^{\mathrm{a}}\end{array}$ & $\begin{array}{c}15.1 \\
\pm 0.7^{\mathrm{a}}\end{array}$ & $\begin{array}{c}15.4 \\
\pm 0.5^{\mathrm{a}}\end{array}$ & 2.7 & $\begin{array}{c}71.0 \\
\pm 2.0^{\mathrm{a}}\end{array}$ & $\begin{array}{l}-0.8 \\
\pm 0.5^{\mathrm{a}}\end{array}$ & $\begin{array}{c}15.9 \\
\pm 2.3^{\mathrm{a}}\end{array}$ & $\begin{array}{c}15.9 \\
\pm 2.1^{\mathrm{a}}\end{array}$ & 8.5 & $\begin{array}{c}74.0 \\
\pm 0.8^{\mathrm{ab}}\end{array}$ & $\begin{array}{l}-2.2 \\
\pm 0.1^{\mathrm{a}}\end{array}$ & $\begin{array}{c}19.0 \\
\pm 0.3^{\text {a }}\end{array}$ & $\begin{array}{c}18.9 \\
\pm 1.2^{\mathrm{ab}}\end{array}$ & 7.8 \\
\hline
\end{tabular}

effect on the color of apple tissue. An increase values of $a^{*}$ parameter was also observed in the case of maltitol. Only when xylitol was used as osmotic agent - decrease of values was observed. Time did not have an influence on $L^{*}$ and $a^{*}$ parameters ( $p$-Value: 0.088 and 0.252 , respectively). An increase of parameter $b^{*}$ (yellowness) during OD was insignificant and ambiguous - statistical analysis did not show any serious influence of time or type of osmotic agent on this parameter ( $p$-Value: 0.235 and 0.462 , respectively). Chroma parameters $C$, denoting color intensification, for apple samples increased when they had been treated in all solutions. However, significant changes were observed in the case of maltitol. The highest value was noted after $180 \mathrm{~min}$ of OD. The changes indicated lightening in color, and concentration of red pigment due to the removal of water from apple samples, mostly in the case of erythritol (because of the highest efficiency). The chroma parameter was correlated with absolute color difference $\Delta E$, which was maximum in the case of xylitol. The lowest absolute differences were noted after osmotic dehydration in erythritol solution. According to Mokrzycki and Tatol [36], an inexperienced observer notices the difference between samples when $2<\Delta E<3.5$. Statistical analysis did not show any significant influence of time ( $p$-Value: 0.146 ), but showed significant impact of osmotic agent ( $p$-Value: 0.010 ) on $\Delta E$. The opposite situation has been reported by Kowalski and Mierzwa [37], when values were significantly higher during extending of time, but pretreatment in glucose, fructose and sucrose was insignificant and resulted in smaller values of $\Delta E$, compared to this research. Djendoubi Mrad et al. [33] reported an increase in the $a^{*}$ (redness), and $b^{*}$ (yellowness) values and invariance $L^{*}$ parameter when pieces of pears had been treated in sucrose solution. Also, chroma values increased during the osmotic dehydration. Naknean et al. [38] in their research osmo-dehydrated cantaloupe in $50 \%$ concentrated solutions (sucrose, maltitol, sorbitol, and invert sugar). The sorbitol- and maltitol-treated samples had higher $L^{*}$ value and lower parameter $a^{*}$ and browning intensity than inverted sugar and sucrose treated samples. The highest brown color was found in inverted sugar-treated sample.

\section{Conclusions}

During the process of OD occurred, the phenomenon of water loss and changes in sugars profile of the apple tissue were mainly observed. In raw apple, the amount of fructose was the most abundant among sugars, followed by sucrose, glucose and trace amounts of sorbitol. As a result of the use of polyols as an osmotic agent in pretreatment, an increase in dry matter content, as well as polyols content in the samples, were noticed. The highest efficiency of the process was observed when erythritol as an osmotic agent had been used, which resulted from the highest osmotic pressure. The absolute color differences $\Delta E$ after process were quite small, chroma values increased during osmotic dehydration. Moreover, the use of erythritol in OD of fruit allowed increase of brightness surface tissue. 


\section{Nomenclature \\ OD osmotic dehydration, \\ WL water loss, (g/g i.d.m.) \\ SG solids gain, (g/g i.d.m.) \\ $m \quad$ sample mass, $(\mathrm{g})$}

\section{References}

[1] Wolfe, K., Wu, X., Liu, R. H. "Antioxidant Activity of Apple Peels", Journal of Agricultural and Food Chemistry, 51(3), pp. 609-614, 2003.

https://oi.org/10.1021/jf020782a

[2] Lata, B. "Relationship between Apple Peel and the Whole Fruit Antioxidant Content: Year and Cultivar Variation", Journal of Agricultural and Food Chemistry, 55(3), pp. 663-671, 2007. https://doi.org/10.1021/jf062664j

[3] Sun, J., Chu, Y.-F., Wu, X., Liu, R. H. "Antioxidant and antiproliferative activities of common fruits", Journal of Agricultural and Food Chemistry, 50(25), pp. 7449-7454, 2002. https://doi.org/10.1021/jf0207530

[4] Hu, F. B., Malik, V. S. "Sugar-sweetened beverages and risk of obesity and type 2 diabetes: Epidemiologic evidence", Physiology \& Behavior, 100(1), pp. 47-54, 2010.

https://doi.org/10.1016/j.physbeh.2010.01.036

[5] Feskanich, D., Ziegler, R. G., Michaud, D. S., Giovannucci, E. L., Speizer, F. E., Willett, W. C., Colditz, G. A. "Prospective Study of Fruit and Vegetable Consumption and Risk of Lung Cancer Among Men and Women", Journal of the National Cancer Institute, 92(22), pp. 1812-1823, 2000.

https://doi.org/10.1093/jnci/92.22.1812

[6] Saulo, A. A. "Sugars and Sweeteners in Foods", Food Safety and Technology, 16, pp. 1-7, 2005.

[7] Grembecka, M. "Sugar alcohols - their role in the modern world of sweeteners: a review", European Food Research and Technology, 241(1), pp. 1-14, 2015.

https://doi.org/10.1007/s00217-015-2437-7

[8] Grabitske, H. A., Slavin, J. L. "Low-Digestible Carbohydrates in Practice", Journal of the American Dietetic Association, 108(10), pp. 1677-1681, 2008.

https://doi.org/10.1016/j.jada.2008.07.010

[9] Campeanu, G., Neata, G., Darjanschi, G. "Chemical Composition of the Fruits of Several Apple Cultivars Growth as Biological Crop", Notulae Botanicae Horti Agrobotanici Cluj-Napoca, 37(2), pp. 161-164, 2009. https://doi.org/10.15835/nbha3723465

[10] Zhang, Y., Li, P., Cheng, L. "Developmental changes of carbohydrates, organic acids, amino acids, and phenolic compounds in 'Honeycrisp' apple flesh", Food Chemistry, 123(4), pp. 1013-1018, 2010.

https://doi.org/10.1016/j.foodchem.2010.05.053

[11] Wu, J., Gao, H., Zhao, L., Liao, X., Chen, F., Wang, Z., Hu, X. "Chemical compositional characterization of some apple cultivars", Food Chemistry, 103(1), pp. 88-93, 2007. https://doi.org/10.1016/j.foodchem.2006.07.030 $s \quad$ dry solids mass of material, $(\mathrm{g})$

$\tau \quad$ time of osmotic dehydration, (min)

Subscripts

o initial

$\tau \quad$ time (min)

[12] Sestras, A. F., Sestras, R. E., Lazar, V. L., Mitre, V., Mitre, I., Ropan, G., Bărbos, A. "The Influence of Fruit Position in the Crown of Trees on the Sugar Content and Morphological Traits of Apple Fruits", Bulletin of University of Agricultural Sciences and Veterinary Medicine Cluj-Napoca. Horticulture, 66(1), pp. 170-176, 2009.

https://doi.org/10.15835/buasvmcn-hort:3820

[13] Mikulič Petkovšek, M., Štampar, F., Veberič, R. "Changes in the inner quality parameters of apple fruit from technological to edible maturity", Acta Agriculturae Slovenica, 93(1), pp. 17-29, 2009. https://doi.org/10.2478/v10014-009-0003-3

[14] Mothibe, K. J., Zhang, M., Mujumdar, A. S., Wang, Y. C., Cheng, X. "Effects of Ultrasound and Microwave Pretreatments of Apple Before Spouted Bed Drying on Rate of Dehydration and Physical Properties", Drying Technology, 32(15), pp. 1848-1856, 2014. https://doi.org/10.1080/07373937.2014.952381

[15] Begić-Akagić, A., Spaho, N., Gasi, F., Drkenda, P., Vranac, A., Meland, M., Salkić, B. "Sugar and Organic Acid Profiles of the Traditional and International Apple Cultivars for Processing", Journal of Hygienic Engineering and Design, 7, pp. 190-196, 2014. [online] Available at: http://www.jhed.mk/filemanager/ JHED\%20Vol.\%207/03.\%20FPP/10.\%20Asima\%20Begi\%C4\%87Akagi\%C4\%87.pdf [Accessed: 30 September 2017]

[16] Ticha, A., Salejda, A. M., Hyšpler, R., Matejicek, A., Paprstein, F., Zadak, Z. "SugarComposition of Apple Cultivars and Its Relationship to Sensory Evaluation", Żywność. Nauka. Technologia. Jakość / Food. Science. Technology. Quality, 4(101), pp. 137-150, 2015. https://doi.org/10.15193/zntj/2015/101/062

[17] Zupan, A., Mikulic-Petkovsek, M., Stampar, F., Veberic, R. "Sugar and phenol content in apple with or without watercore", Journal of the Science of Food and Agriculture, 96(8), pp. 2845-2850, 2016. https://doi.org/10.1002/jsfa.7453

[18] Assis, F. R., Morais, R. M. S. C., Morais, A. M. M. B. "Mathematical Modelling of Osmotic Dehydration Kinetics of Apple Cubes", Journal of Food Processing and Preservation, 41(3), article ID: e12895, 2017. https://doi.org/10.1111/jfpp.12895

[19] Bialik, M., Wiktor, A., Latocha, P., Gondek, E. "Mass Transfer in Osmotic Dehydration of Kiwiberry: Experimental and Mathematical Modelling Studies", Molecules, 23(5), article ID: 1236, 2018. https://doi.org/10.3390/molecules23051236

[20] Cichowska, J., Żubernik, J., Czyżewski, J., Kowalska, H., WitrowaRajchert, D. "Efficiency of Osmotic Dehydration of Apples in Polyols Solutions", Molecules, 23(2), article ID: 446, 2018. https://doi.org/10.3390/molecules23020446 
[21] Cichowska, J., Figiel, A., Stasiak-Różańska, L., WitrowaRajchert, D. "Modeling of Osmotic Dehydration of Apples in Sugar Alcohols and Dihydroxyacetone (DHA) Solutions", Foods, 8(1), article ID: 20, 2019. https://doi.org/10.3390/foods8010020

[22] Association of Official Analytical Chemists International (Horwitz, W., Laimer Jr., G. W. (eds.)) "Official Methods of Analysis of AOAC International", AOAC International, Gaithersburg, MD, USA, 2011.

[23] Devic, E., Guyot, S., Daudin, J.-D., Bonazzi, C. "Effect of Temperature and Cultivar on Polyphenol Retention and Mass Transfer during Osmotic Dehydration of Apples", Journal of Agricultural and Food Chemistry, 58(1), pp. 606-614, 2010. https://doi.org/10.1021/jf903006g

[24] Muresan, A. E., Muste, S., Borsa, A., Vlaic, R. A., Muresan, V. "Evaluation of Physical-Chemical Indexes, Sugars, Pigments and Phenolic Compounds of Fruits from Three Apple Varieties at the End of Storage Period", Bulletin of University of Agricultural Sciences and Veterinary Medicine Cluj-Napoca. Food Science and Technology, 71(1), pp. 45-50, 2014. https://doi.org/10.15835/buasvmen-fst:10111

[25] Chareoansiri, R., Kongkachuichai, R. "Sugar profiles and soluble and insoluble dietary fiber contents of fruits in Thailand markets", International Journal of Food Sciences and Nutrition, 60(Supplement 4), pp. 126-139, 2009. https://doi.org/10.1080/09637480802609376

[26] Wang, Z., Wei, T., Zhang, M. "Effects of Vacuum and Normal Pressure Impregnation on Water Loss and Solid Gain of Apple (Malus pumila Mill)", Journal of Food Processing and Preservation, 39(6), pp. 1045-1050, 2015. https://doi.org/10.1111/jfpp.12319

[27] Li, B. W., Andrews, K. W., Pehrsson, P. R. "Individual Sugars, Soluble, and Insoluble Dietary Fiber Contents of 70 High Consumption Foods", Journal of Food Composition and Analysis, 15(6), pp. 715-723, 2002.

https://doi.org/10.1006/jfca.2002.1096

[28] Füzfai, Z., Katona, Z. F., Kovács, E., Molnár-Perl, I. "Simultaneous Identification and Quantification of the Sugar, Sugar Alcohol, and Carboxylic Acid Contents of Sour Cherry, Apple, and Ber Fruits, as Their Trimethylsilyl Derivatives, by Gas ChromatographyMass Spectrometry", Journal of Agricultural and Food Chemistry, 52(25), pp. 7444-7452, 2004.

https://doi.org/10.1021/jf040118p
[29] Wang, R., McCormick, R., Xuan, H., Streif, J. "Distribution of Sugar and Organic Acid Components within the KOB Heritage Apple Cultivar Collection", Acta Horticulturae, 858, pp. 89-97, 2010.

https://doi.org/10.17660/ActaHortic.2010.858.10

[30] Aprea, E., Charles, M., Endrizzi, I., Corollaro, M. L., Betta, E., Biasioli, F., Gasperi, F. "Sweet taste in apple: the role of sorbitol, individual sugars, organic acids and volatile compounds", Scientific Reports, 7, article ID: 44950, 2017. https://doi.org/10.1038/srep44950

[31] Yamaki, S., Ino, M. "Alteration of Cellular Compartmentation and Membrane Permeability to Sugars in Immature and Mature Apple Fruit", Journal of the American Society for Horticultural Science, 117(6), pp. 951-954, 1992. https://doi.org/10.21273/JASHS.117.6.951

[32] Held, C., Neuhaus, T., Sadowski, G. "Compatible solutes: Thermodynamic properties and biological impact of ectoines and prolines", Biophysical Chemistry, 152(1-3), pp. 28-29, 2010. https://doi.org/10.1016/j.bpc.2010.07.003

[33] Djendoubi Mrad, N., Boudhriuoa Mihoubi, N., Kechaou, N., Courtois, F., Bonazzi, C. "Effect of Osmo-dehydration Conditions on the Quality Attributes of Pears", Journal of Food Processing \& Technology, 4(8), article ID: 256, 2013. https://doi.org/10.4172/2157-7110.1000256

[34] de Cock, P. "10 Erythritol", In: Sweeteners and Sugar Alternatives in Food Technology, Wiley-Blackwell, Chichester, West Sussex, UK, 2012, pp. 215-241.

[35] Ciurzyńska, A., Cichowska, J., Kowalska, H., Czajkowska, K., Lenart, A. "Osmotic dehydration of Braeburn variety apples in the production of sustainable food products", International Agrophysics, 32(1), pp. 141-146, 2018. https://doi.org/10.1515/intag-2016-0099

[36] Mokrzycki, W. S., Tatol, M. "Color difference Delta E - A survey", Machine Graphics and Vision, 20(4), pp. 383-412, 2011.

[37] Kowalski, S. J., Mierzwa, D. "Influence of Osmotic Pretreatment on Kinetics of Convective Drying and Quality of Apples", Drying Technology, 31(15), pp. 1849-1855, 2013. https://doi.org/10.1080/07373937.2013.833518

[38] Naknean, P., Maneyam, R., Kam-onsri, A. "Effect of Different Osmotic Agents on the Physical, Chemical and Sensory Properties of Osmo-Dried Cantaloupe", Chiang Mai Journal of Science, 40(3), pp. 427-439, 2013. 